J. Amer. Soc. Hort. SCI. 115(3):482-486. 1990.

\title{
Enhancement of Growth and Flowering of Triteleia laxa by Ethylene
}

\author{
Susan S. Han ${ }^{1}$, Abraham H. Halevy ${ }^{2}$, Roy M. Sachs, and Michael S. Reid \\ Department of Environmental Horticulture, University of California, Davis, CA 95616 \\ Additional index words. corms, apical meristem size, carbohydrate, respiration rate, brodiaea
}

\begin{abstract}
Exposure of dormant corms of Triteleia laxa 'Queen Fabiola' to 20 ppm $\mathrm{C}_{2} \mathrm{H}_{4}$ for 7 days promoted flowering of small corms and resulted in increased apical meristem size, early sprouting, early flowering, more flowers per Inflorescence, and increased fresh weight of daughter corms and cormels. The respiration rate of the C\&treated corms increased to four to five times that of the controls during the 7-day treatment, declined markedly after termination of the $\mathrm{C}_{2} \mathrm{H}_{4}$ treatment, but remained higher than that of the controls. The $\mathrm{C}_{2} \mathrm{H}_{4}$ effects were associated with increased growth rate and consequently a greater final size of the apical meristem (determined by scanning electron microscopy). Leaves produced by $\mathrm{C}_{2} \mathrm{H}_{4}$-treated corms were wider, longer, and weighed more than those of the controls.
\end{abstract}

Ethylene is a plant hormone that has diverse effects on a wide range of plant tissues (Reid, 1987). Depending on the species, $\mathrm{C}_{2} \mathrm{H}_{4}$ may promote flower initiation, stimulate flower development, inhibit flower induction, or cause abortion. Japanese bulb growers found that, after burning iris fields in the autumn (to control leaf diseases), a greater proportion of the bulbs subsequently flowered and the crop flowered earlier (Elphinstone and Rees, 1985). These useful responses were shown to be due to the smoke, and specifically to $\mathrm{C}_{2} \mathrm{H}_{4}$ in the smoke (Uyemura and Imanishi, 1983). Ethylene has been shown to affect both the sprouting date and the flowering of a range of geophytes (Elphinstone and Rees, 1985; Ginzburg, 1974; Halevy et al., 1970; Imanishi and Fortainier, 1982; Imanishi, 1983; Schipper, 1982; Uyemura and Imanishi, 1983, 1984; Vacha and Harvey, 1927). The physiological responses of these organs to the $\mathrm{C}_{2} \mathrm{H}_{4}$ treatment and the mechanism by which $\mathrm{C}_{2} \mathrm{H}_{4}$ breaks the dormant state or affects flowering are still unexplored.

Triteleia laxa (syn. Brodiaea laxa) has gained popularity in recent years as a cut-flower crop. Because of the advantageous effects of $\mathrm{C}_{2} \mathrm{H}_{4}$ on growth and flowering of some bulbous plants, we studied its action on growth and flowering of Triteleia laxa cv. Queen Fabiola.

\section{Materials and Methods}

Plant materials. Triteleia laxa 'Queen Fabiola' corms were grown outdoors in Davis, Calif., under natural conditions. For most experiments, dormant corms (no visible shoots) with an average weight of $1.1 \mathrm{~g}$ were used as experimental material.

Ethylene and growth and development. Corms were exposed to a flowing stream of air or of air containing $\mathrm{C}_{2} \mathrm{H}_{4}(20 \mathrm{ppm}$ for 1 day or 7 days or $40 \mathrm{ppm}$ for 7 days) in the laboratory in June 1986. Flow rates were sufficient to prevent significant accumulation of $\mathrm{CO}_{2}$. Immediately after ethylene treatment, individual corms were planted with their tops $5 \mathrm{~cm}$ below the soil surface in PVC containers containing UC mix [1 sand : 1 redwood bark : 1 peat (by volume)] and grown at 18/10C day/night

Received for publication 12 Dec. 1988. This study was partially supported by BARD research project no. 1-795-84. The cost of publishing this paper was defrayed in part by the payment of page charges. Under postal regulations, this paper therefore must be hereby marked advertisement solely to indicate this fact.

${ }^{1}$ Permanent address: Dept. of Plant and Soil Sciences, French Hall, Univ. of Massachusetts, Amherst, MA 01003.

${ }^{2}$ Permanent address: Faculty of Agriculture, The Hebrew Univ. of Jerusalem. Rehovot, 76-100, Israel. in a greenhouse under natural daylengths. The inflorescences were harvested when the first flowers reached anthesis. The fresh weight of the daughter corm and cormels was measured when the leaves had senesced. There were 10 replications (one corm each) per treatment.

Effect of ethylene and corm size. Corms were graded according to weight into six size classes and 10 replicate corms of each size class were exposed for 1 week to $20 \mathrm{ppm}$ ethylene. The corms were then planted individually in UC mix and grown in a greenhouse [24/18C (day/night)] under long-day conditions $\left(8 \mathrm{hr}\right.$ of natural light plus $16 \mathrm{hr}$ of $5 \mu \mathrm{mol} \cdot \mathrm{s}^{-1} \cdot \mathrm{m}^{-2}$ incandescent light).

Determination of respiration rate. Individual corms were placed in 25-ml vials ventilated $\left(0.2\right.$ liter.hr $\left.{ }^{-1}\right)$ with either air or 20 ppm $\mathrm{C}_{2} \mathrm{H}_{4}$ at room temperature. One milliliter aliquots of the exit air stream were withdrawn and the $\mathrm{CO}_{2}$ content of the air was determined using an ADC infra-red gas analyzer type 2252B-SS (Analytical Development, Hoddeson, England).

Determination of carbohydrate mobilization. Ethylene-treated (20 ppm for 7 days) and control corms were planted in a 24/ $18 \mathrm{C}$ greenhouse and grown under continuous light $(8 \mathrm{hr}$ natural light plus $16 \mathrm{hr}$ of $5 \mu \mathrm{mol} \cdot \mathrm{s}^{-1} \cdot \mathrm{m}^{-2}$ incandescent light). Plants were harvested at intervals and the dry weights of various organs and the carbohydrate content of the corms were determined: Each corm was divided into two sections, the inner ring (sampled by a 4-mm cork borer) and the outer ring (the rest of the corm tissue). The tissues were freeze-dried immediately, and 100-mg samples were ground to a fine powder with a mortar and pestle and extracted overnight in $5 \mathrm{ml}$ of $70 \%$ ethanol containing $2 \mathrm{mM} \mathrm{Ca}$-acetate. The samples were centrifuged and the pellets were re-extracted three times. The supernatants were collected for determination of soluble sugars. The ethanol-insoluble residues were dried in air for starch analysis.

The starch in the samples was solubilized by adding $1 \mathrm{ml}$ saturated $\mathrm{Ca}(\mathrm{OH})_{2}$ and autoclaving for $20 \mathrm{~min}$. Samples were cooled to room temperature before adding $1.5 \mathrm{ml} \mathrm{Na-phosphate}$ buffer ( $\mathrm{pH} 4.6$ ) and $5 \mathrm{ml}$ of a $10 \mathrm{mg} \cdot \mathrm{ml}^{-1}$ solution of amylglucosidase (EC 3.2.1.3) (Sigma, St. Louis, enzyme activity 12,000 units/g protein). The samples were incubated in a 55C water bath with continuous shaking overnight, after which glucose released by hydrolysis was determined using the hexokinase (EC 2.7.1.1) method (Carroll et al., 1970).

Total soluble sugar content was estimated by a modification of the anthrone method of Yemm and Willis (1954). The ethanolextracted solutions were blow-dried and redissolved in deionized water. Aliquots $(20 \mu \mathrm{l})$ of the dissolved sugars were layered 
Table 1. Effect of ethylene on the sprouting, flowering, and corm yield of Triteleia

\begin{tabular}{|c|c|c|c|c|c|c|}
\hline \multirow{2}{*}{\multicolumn{2}{|c|}{ Ethylene }} & \multicolumn{2}{|c|}{ Interval } & \multirow{3}{*}{$\begin{array}{l}\text { Flowers per } \\
\text { inflorescence } \\
\text { (no.) }\end{array}$} & \multirow{3}{*}{$\begin{array}{l}\text { Scape } \\
\text { length } \\
(\mathrm{cm})\end{array}$} & \multirow{3}{*}{$\begin{array}{l}\text { Daughter } \\
\text { corms fresh wty } \\
\text { (g) }\end{array}$} \\
\hline & & \multirow{2}{*}{$\begin{array}{c}\text { To } \\
\text { sprouting } \\
\text { (days) }\end{array}$} & \multirow{2}{*}{$\begin{array}{c}\text { To } \\
\text { flowering } \\
\text { (days) }\end{array}$} & & & \\
\hline $\begin{array}{l}\text { Concn } \\
\text { (ppm) }\end{array}$ & $\begin{array}{c}\text { Duration } \\
\text { (days) }\end{array}$ & & & & & \\
\hline $\begin{array}{r}0 \\
20 \\
20 \\
40\end{array}$ & $\begin{array}{l}- \\
1 \\
7\end{array}$ & $\begin{array}{l}104 \mathrm{a}^{2} \\
96 \mathrm{a} \\
78 \mathrm{~b} \\
81 \mathrm{~b}\end{array}$ & $\begin{array}{l}274 \mathrm{a} \\
253 \mathrm{~b} \\
231 \mathrm{c} \\
228 \mathrm{c}\end{array}$ & $\begin{array}{l}15 \mathrm{a} \\
18 \mathrm{ab} \\
27 \mathrm{~b} \\
26 \mathrm{~b}\end{array}$ & $\begin{array}{l}40 \mathrm{a} \\
44 \mathrm{a} \\
43 \mathrm{a} \\
45 \mathrm{a}\end{array}$ & $\begin{array}{l}7.4 \mathrm{a} \\
8.1 \mathrm{a} \\
9.9 \mathrm{a} \\
9.2 \mathrm{a}\end{array}$ \\
\hline
\end{tabular}

${ }^{\mathrm{z}}$ Means separated within columns by Duncan's multiple range test, $P=0.05$.

${ }^{\mathrm{y}}$ Combined fresh weight of the daughter corm and cormels.

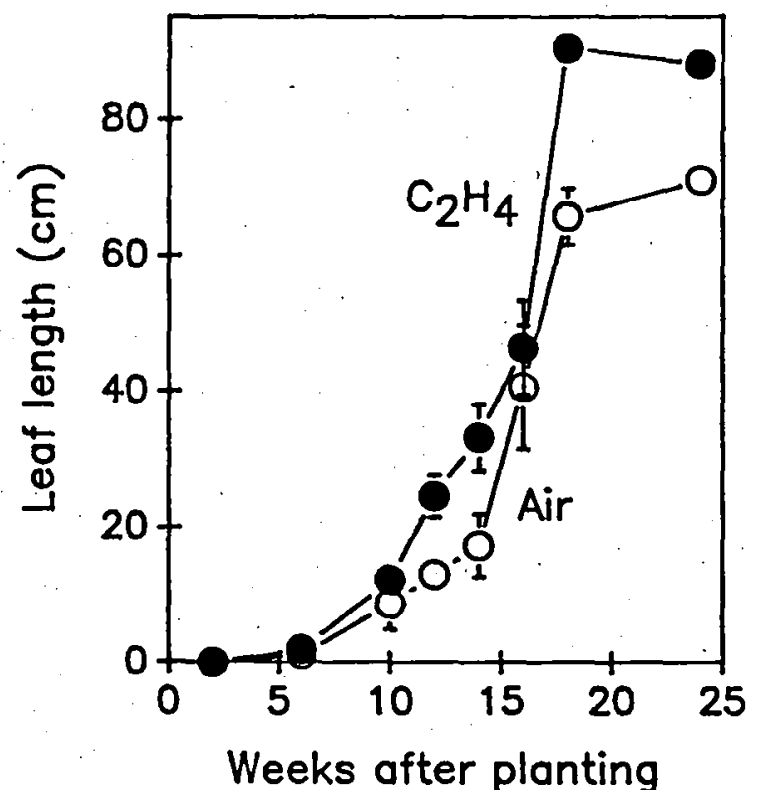

Fig. 1. Effect of 20 ppm ethylene for 7 days on rate of elongation of Triteleia laxa 'Queen Fabiola' leaves. SE bars smaller than the symbols are not shown.

on cold anthrone reagent, cooled for $5 \mathrm{~min}$, heated in a boiling water bath for $10 \mathrm{~min}$, and then cooled for an additional $5 \mathrm{~min}$ before determination of absorbance at $600 \mathrm{~nm}$.

Determination of apical meristem size. Samples of the shoot axis from corms of $\mathrm{C}_{2} \mathrm{H}_{4}$-treated and control plants were collected at intervals after planting. They were fixed with $2 \%$ glutaraldehyde in $0.1 \mathrm{M}$ phosphate buffer $(\mathrm{pH} 7)$ and dehydrated by passing through an ethanol series, critical-point-dried with $\mathrm{CO}_{2}$, and examined and photographed using an ISI DS130 scanning electron microscope (SEM) (International Scientific Instrument, Pleasanton, Calif.).

\section{Results}

Effects of ethylene on growth and flowering. Ethylene treatment reduced the number of days to sprouting (Table 1); exposure to $\mathrm{C}_{2} \mathrm{H}_{4}$ for 1 week was more effective than for 1 day. Leaves from the $\mathrm{C}_{2} \mathrm{H}_{2}$-treated corms grew faster and were longer (Fig. 1), wider, and had greater dry weight than the controls (Fig. 4 middle). Ethylene treatment reduced the number of days to anthesis of the first flower by 2 or 5 weeks for the 1- or 7day treatments, respectively. Ethylene treatment for 7 days increased the number of flowers per inflorescence but had no effect on scape length. Although the combined fresh weight of
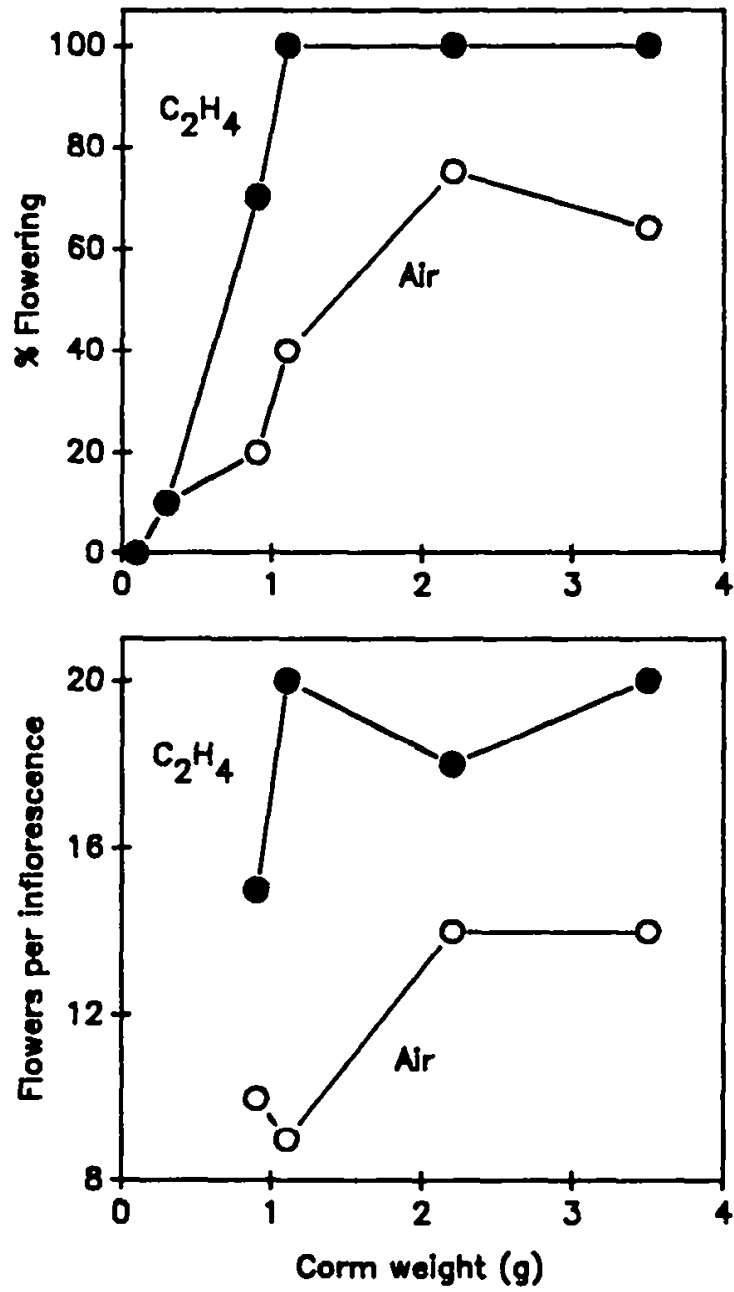

Fig. 2. Effect of treatment of different-size Triteleia laxa corms with $20 \mathrm{ppm}$ ethylene for 7 days on (top) flowering percentage, and (bottom) number of flowers per inflorescence (bars indicate SE of the means). Regression analysis reveals highly significant positive regressions of flowering percent with increasing corm size $(\mathrm{y}=55 \mathrm{x}$ $-9.5 \mathrm{x}^{2}-9, r^{2}=0.94$ for control corms; $\mathrm{y}=169 \mathrm{x}-71 \mathrm{x}^{2}+$ $9 \mathrm{x}^{3}-24, \mathrm{r}^{2}=0.97$ for ethylene-treated corms).

the daughter corm and cormels from the ethylene-treated plants appeared substantially higher than that of the controls, the variance in the data was such that the difference was not statistically significant (Table 1).

Effect of ethylene and corm size. Corms $<0.3 \mathrm{~g}$ did not flower regardless of pretreatment (Fig. 2 top), but ethylene treatment 
of larger corms increased the percent flowering and the number of flowers per inflorescence (Fig. 2 bottom), regardless of corm size. For smaller-sized corms, there was a particularly marked stimulation of flowering. Ethylene treatment, for example, increased the proportion of flowering corms weighing $0.9 \mathrm{~g}$ from $20 \%$ to $70 \%$.

Effect of ethylene on respiration rate. The respiration rate of brodiaea corms treated with $20 \mathrm{ppm} \mathrm{C}_{2} \mathrm{H}_{4}$ increased rapidly (Fig. 3). Peak respiration rate of the $\mathrm{C}_{2} \mathrm{H}_{4}$-treated corms was about five to seven times that of the controls. Respiration fell markedly after the removal of $\mathrm{C}_{2} \mathrm{H}_{4}$ (Fig. 3) but was still two to three times higher than that of the controls 4 days later and stayed slightly higher throughout the experimental period.

Effect of ethylene on carbohydrate mobilization. The dry weight of the mother corms of $\mathrm{C}_{2} \mathrm{H}_{4}$-treated plants decreased more rapidly than that of control corms (Fig. 4 top). The dry weight of the leaves and the combined dry weights of the daughter corms and cormels in $\mathrm{C}_{2} \mathrm{H}_{4}$-treated plants increased earlier than those of the controls and eventually reached $160 \%$ and $130 \%$ that of the controls, respectively (Fig. 4 middle and bottom). Analysis of starch and total soluble sugars concentration (on a dry-weight basis) in the corms after planting did not reveal any differences between $\mathrm{C}_{2} \mathrm{H}_{4}$-treated and control corms (data not shown).

Effect of ethylene on the shoot axis and the apical meristem. One week after planting, the main axis (comprised of a leaf sheath and two leaf primordia) of the $\mathrm{C}_{2} \mathrm{H}_{4}$-treated corms was longer $(1.35 \pm 0.03 \mu \mathrm{m})$ and wider $(1.17 \pm 0.04 \mu \mathrm{m})$ than that of the controls $(0.88 \pm 0.08 \mu \mathrm{m}$ vs. $0.82 \pm 0.03 \mu \mathrm{m})$, respectively. A comparison of growth of the apical meristem of $\mathrm{C}_{2} \mathrm{H}_{4}$-treated and control corms is shown in Fig. 5. The apical meristems of the $\mathrm{C}_{2} \mathrm{H}_{4}$-treated corms were already larger than the controls after 1 week, and increased after planting at a rate of $22 \mu \mathrm{m} \cdot \mathrm{week}^{-1}$, reaching $\approx 350 \mu \mathrm{m}$ in diameter when they changed from a vegetative to a reproductive phase 7 to 8 weeks after planting. In contrast, the apical meristems of the controls increased at a rate of $11 \mu \mathrm{m} \cdot$ week $^{-1}$ four weeks after planting and reached only $250 \mu \mathrm{m}$ when they changed from vegetative to reproductive.

\section{Discussion}

In the wild, mature plants of Triteleia laxa bloom once a year, in late spring to early summer. Corms harvested after the

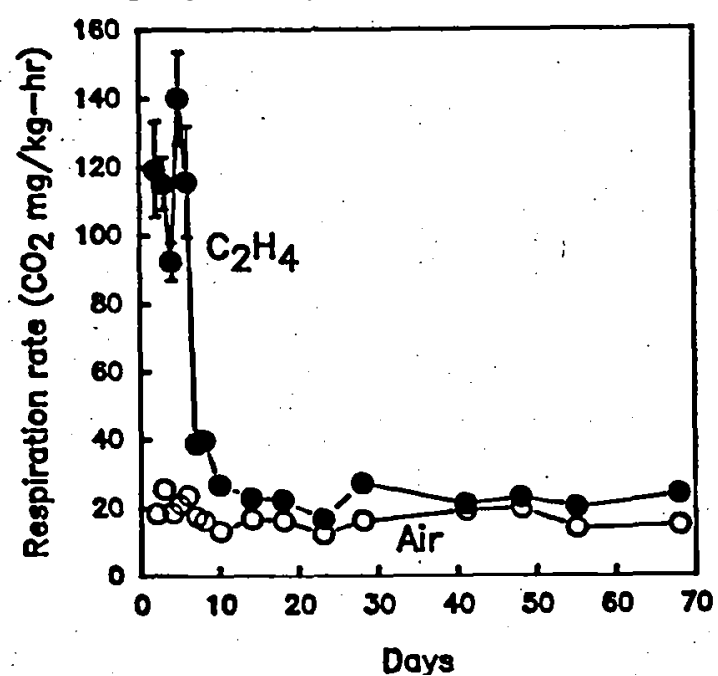

Fig. 3. Effect of $20 \mathrm{ppm}$ ethylene for 7 days on respiration rate of Triteleia laxa 'Queen Fabiola' corms. SE bars smaller than the symbols are not shown.
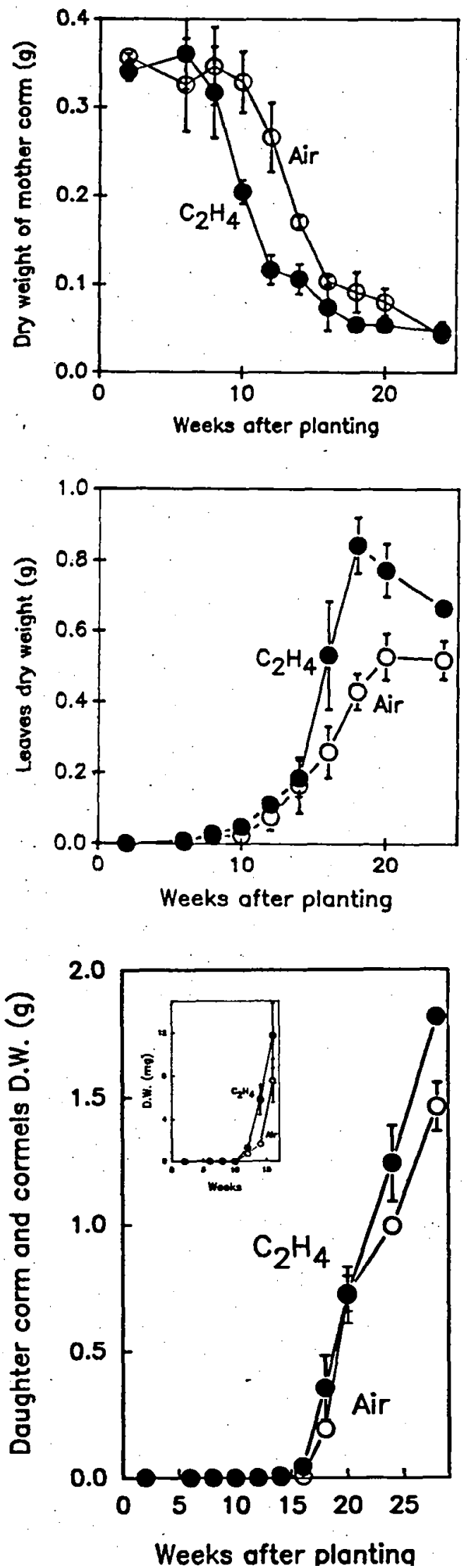

Fig. 4. Effect of $20 \mathrm{ppm}$ ethylene for 7 days on dry weight of Triteleia laxa 'Queen Fabiola' (top) mother corm, (middle) leaves, and (bottom) combined weight of daughter corm and cormels (inset shows data of early growth). 


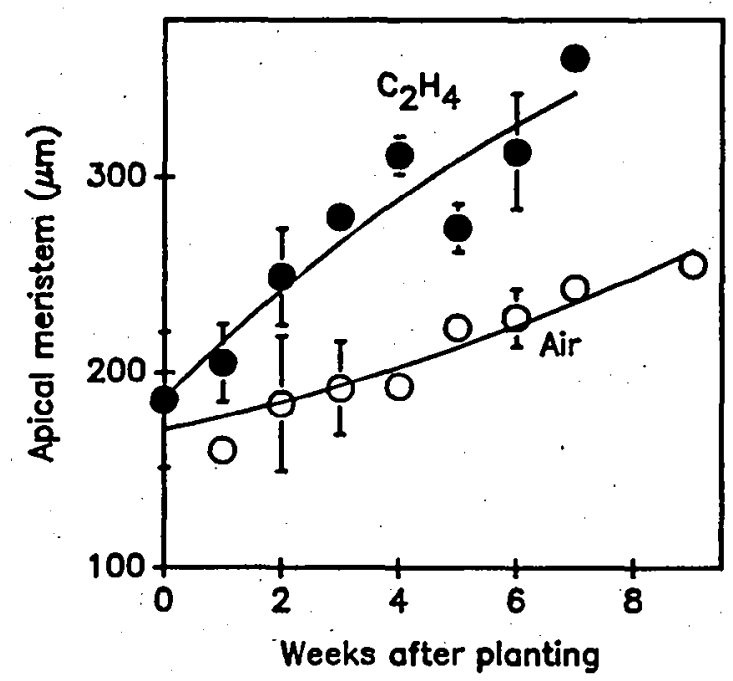

Fig. 5. Effect of $20 \mathrm{ppm}$ ethylene for 7 days on diameter of the apical meristems. SE bars smaller than the symbols are not shown.

leaves have senesced remain dormant until early to mid-fall. Exposure of dormant brodiaea corms to $\mathrm{C}_{2} \mathrm{H}_{4}$ caused early sprouting, early flowering, and increased number of flowers per inflorescence (Table 1). The optimum concentration and exposure time for flowering responses of geophytes to $\mathrm{C}_{2} \mathrm{H}_{4}$ varies between species (Elphinstone and Rees, 1985; Ginzburg, 1974; Halevy et al., 1970; Imanishi and Fortainier, 1982; Imanishi, 1983; Schipper, 1982; Uyemura and Imanishi, 1984). In brodiaea, the response to $\mathrm{C}_{2} \mathrm{H}_{4}$ was maximal at concentrations $>20$ ppm and exposure times longer than 1 day. In contrast, marked stimulation of flowering in small (8.5 to $10.5 \mathrm{~g}$ ) iris bulbs occurs after as little as $1 \mathrm{hr}$ of exposure to $10 \mathrm{ppm} \mathrm{C}_{2} \mathrm{H}_{4}$ (Imanishi and Yue, 1985).

No explanation has yet been advanced for the striking effect of $\mathrm{C}_{2} \mathrm{H}_{4}$ on the flowering of geophytes. The pronounced effect of $\mathrm{C}_{2} \mathrm{H}_{4}$ on sprouting of potatoes is associated with increased respiration rate (Reid and Pratt, 1972) and mobilization of carbohydrates (Huelin and Barker, 1939). If the soluble carbohydrate content of dormant geophyte propagules increased following $\mathrm{C}_{2} \mathrm{H}_{4}$ treatment, this could be the cause of stimulated growth and flower induction. Induction of flowering by chemical or environmental factors has been suggested to be related to their influence on assimilate supply and distribution (Sachs, 1977). Although the respiration of dormant brodiaea corms increased rapidly in response to $\mathrm{C}_{2} \mathrm{H}_{4}$ treatment (Fig. 3), we could measure no significant effect of $\mathrm{C}_{2} \mathrm{H}_{4}$ on their carbohydrate content. These data suggest that changes in carbohydrate mobilization are unlikely to be an initial mechanism for the effects of $\mathrm{C}_{2} \mathrm{H}_{4}$ on growth and flowering in these geophytes.

Another possible explanation of the striking effects of ethylene on growth and flowering of brodiaea is that ethylene may be releasing the corms from dormancy. Ethylene-treated corms sprout 26 days earlier than controls (Table 1), which could be interpreted as a reduction in dormancy. The acceleration of flowering (43 days) is, however, greater than the acceleration of sprouting, indicating that dormancy release cannot be the only mechanism of ethylene action. The improved quality of the inflorescences and other morphological attributes of the ethylene-treated corms also indicate actions of this regulator in addition to dormancy breaking. In particular, the striking enhancement of flowering of marginal brodiaea corms in response to ethylene (Fig. 2) suggests a specific effect on the induction of flowering, similar to the responses seen in other geophytes (Halevy, 1986).

Examination of the effects of $\mathrm{C}_{2} \mathrm{H}_{4}$ on the morphology of the apical meristem of brodiaea corms suggests an alternative mechanism for the action of $\mathrm{C}_{2} \mathrm{H}_{4}$ in geophytes. The apical meristems of $\mathrm{C}_{2} \mathrm{H}_{4}$-treated corms grew at twice the rate of those in control corms (Fig. 5). Meristems from ethylene-treated corms were already considerably larger than the controls 1 week after the end of the $\mathrm{C}_{2} \mathrm{H}_{4}$ treatment. We suggest that this expansion may be the primary effect of ethylene on flowering of brodiaea and probably other geophytes. We know that the ability to flower correlates with size of the apical dome in lilies (Kohl, 1967) and in iris (Doss and Christian, 1979). We have shown in brodiaea (Han et al., 1990) that flowering and the number of flowers per inflorescence are directly related to the size of the apical meristem. The effects of ethylene on flowering of marginal-sized bulbs is consistent with our meristem-growth hypothesis. Rapid growth of the meristem in small corms treated with ethylene would produce an apex comparable to that of larger control corms, and correspondingly higher flowering potential.

Electron micrographs of control and $\mathrm{C}_{2} \mathrm{H}_{4}$-treated meristems did not reveal any detectable change in cell size (data not shown), suggesting that the rapid enlargement of the apical meristem in $\mathrm{C}_{2} \mathrm{H}_{4}$-treated corms may be the result of stimulated cell division.

The stimulatory effect of $\mathrm{C}_{2} \mathrm{H}_{4}$ on the apical meristem of brodiaea is accompanied by early enlargement of the shoot axis, which results in longer and wider leaves (Figs. 1 and 3). Brodiaea plants only have two leaves, so the increased photosynthetic capacity resulting from this increased leaf area may also play a role in the greater quality of flowers from ethylene-treated corms, and may also explain the apparent increase in weight of their daughter corms and cormels produced by $\mathrm{C}_{2} \mathrm{H}_{4}$-treated corms (Table 1).

\section{Literature Cited}

Carroll, J.J., N. Smith, and A.L. Babson. 1970. A colorimetric serum glucose determination using hexokinase and glucose-6-phosphate dehydrogenase. Biochem. Med. 4:171-180.

Doss, R.P. and J.K. Christian. 1979. Relationships between bulb size, apex size, and flowering in bulbous iris cv. Ideal. Physiol. Plant. 45:215-218.

Elphinstone, E.D. and A.R. Rees. 1985. Forcing out the Dutch to flower all year round in the UK. Grower. Jan. p. 33-39.

Ginzburg, C. 1974. Studies on the role of ethylene in gladiolus cormel germination. Plant Sci. Lett. 2:133-138.

Halevy, A.H. 1986. Recent advances in the use of growth substances in ornamental horticulture. p. 391-398. In: M. Bopp (ed.). Plant growth substances 1985. Springer-Verlag, Berlin.

Halevy, A.H., R. Shillo, and S. Simchon. 1970. Effect of 2-chloroethanephosphonic acid (ethrel) on health, dormancy, and flower and corm yield of gladioli. J. Hort. Sci. 45:427-434.

Han, S.S., A.H. Halevy, R.M. Sachs, and M.S. Reid. 1990. Factors affecting flowering and corm yield of Triteleia laxa 'Queen Fabiola'. J. Amer. Soc. Hort. Sci. (In press.)

Huelin, F.E. and J. Barker. 1939. The effect of ethylene on the respiration and carbohydrate metabolism of potatoes. New Phytol. 28:85104.

Imanishi, H. and E.J. Fortainier. 1982. Effects of exposing freesia corms to ethylene or to smoke on dormancy-breaking and flowering. Scientia Hort. 18:381-389.

Imanishi, H. 1983. Effects of exposure of bulbs to smoke and ethylene on flowering of Narcissus tazetta cultivar 'Grand Soleil d'Or'. Scientia Hort. 21:173-180. 
Imanishi, H. and D. Yue. 1985. Effects of duration of exposure to ethylene on flowering of Dutch iris. Acta Hort. 177:141-145.

Kohl, H.C. 1967. Correlation between rate of initiation and apex diameter of Lilium longiflorum cultivar 'Ace'. HortScience 2:15-16.

Reid, M.S. 1987. Ethylene in plant growth, development, and senescence. p. 257-279. In: P.J. Davies (ed.). Plant hormones and their roles in plant growth and development. Martinus Nijhoff, Boston.

Reid, M.S. and H.K. Pratt. 1972. Effects of ethylene on potato tuber respiration. Plant Physiol. 49:252-255.

Sachs, R.M. 1977. Nutrient diversion: An hypothesis to explain the chemical control of flowering. HortScience 12:220-222.

Schipper, J.A. 1982. A smoke treatment inducing flower formation in iris bulbs. Netherlands J. Agr. Sci. 29:173-177.
Uyemura, S. and H. Imanishi. 1983. Effects of gaseous compounds in smoke on dormancy release in freesia corms. Scientia Hort. 20:9199.

Uyemura, S. and H. Imanishi. 1984. Effects of duration of exposure to ethylene on dormancy release in freesia corms. Scientia Hort. 22:383-390.

Vacha, G.A. and R.B. Harvey. 1927. The use of ethylene, propylene and similar compounds in breaking the rest Period of tubers, bulbs, cuttings, and seeds. Plant Physiol. 2:187-193.

Yemm, E.W. and A.J. Willis. 1954. The estimation of carbohydrates in plant extracts by anthrone. Biochem. J. 47:508-514.

J. Amer. SOC. HorT. SCI. 115(3):486-491. 1990

\title{
A Model for Net Photosynthesis of Rose Leaves as a Function of Photosynthetically Active Radiation, Leaf Temperature, and Leaf Age
}

\author{
J.H. Lieth ${ }^{1}$ and C.C. Pasian ${ }^{2}$ \\ Department of Environmental Horticulture, University of California, Davis, CA 95616 \\ Additional index words. Rosa hybrida, mathematical model, irradiance
}

\begin{abstract}
A mathematical description for the relationship between the rate of rose (Rosa hybrida L.) leaf net photosynthesis and photosynthetically active radiation, leaf temperature, and leaf age is developed. The model provides a tool for the prediction of these rates for leaves growing in a rose crop canopy.
\end{abstract}

Mathematical crop models are valuable tools for optimizing production practices for many agronomic crops (Whisler et al., 1986). Such models predict crop growth and development in response to environmental factors such as irradiance, temperature, and $\mathrm{CO}_{2}$ concentration. One of the most feasible approaches in developing crop simulation models is to use modules (Reynolds et al., 1988) where each module focuses exclusively on one physiological phenomenon. Typically, there are modules for photosynthesis, respiration, assimilate partitioning, and various other processes that may be of specific interest, such as fruit or leaf abscission. This paper describes the development of one such module for a rose crop model: a net leaf photosynthesis model responsive to photosynthetically active radiation (PAR), leaf temperature, and leaf age.

Aikin and Hanan (1975) and Bozarth et al. (1982) measured the photosynthetic response of roses to irradiance. Both observed a pattern of saturation with increasing light levels. We (Pasian and Lieth, 1989) found a non-rectangular hyperbola to be a suitable mathematical description of the PAR response of rose leaves. We investigated the suitability of this model at various combinations of four temperatures and leaf ages and indicated that additional data over a wider range of leaf temperatures and ages were needed to incorporate these variables into the model.

Additional environmental variables can be incorporated into such a photosynthesis PAR response model by letting the sat-

Received for publication 28 Nov. 1988. This project was funded in part by a grant from the Joseph H. Hill Memorial Foundation and Roses Incorporated. The cost of publishing this paper was defrayed in part by the payment of page charges. Under postal regulations, this paper therefore must be hereby marked advertisement solely to indicate this fact.

${ }^{1}$ Assistant Professor and Extension Specialist.

${ }^{2}$ Graduate Research Assistant. urated net photosynthetic rate $\left(\mathrm{P}_{\mathrm{m}}\right)$, usually a parameter in such a model, vary with these variables. This approach is possible for leaf temperature because its effect on net photosynthesis is manifested mainly through its effect on $\mathrm{P}_{\mathrm{m}}$ (Johnson and Thornley, 1984). Leaf age has also been shown to have an impact on $\mathrm{P}_{\mathrm{m}}$ (Catsky and Ticha, 1980; Constable and Rawson, 1980; Field and Mooney, 1983) so that it can be dealt with in the same way. The objectives of this study were to: 1) supplement our earlier data (Pasian and Lieth, 1989); 2) formulate a mathematical model for net photosynthesis incorporating PAR, leaf temperature, and leaf age; and 3) calibrate this model.

\section{Materials and Methods}

All net 'Cara Mia' rose leaf photosynthesis rates were collected using a LI-COR 6000 photosynthesis meter (LI-COR, Lincoln, Neb.) (Pasian and Lieth, 1989). Plants were grown in containers in a greenhouse and moved to the site where measurements were to take place (usually a growth chamber). Measurements were made under a 1000-W metal-halide lamp suspended in a structure consisting of a metal tube framework.

Temperature response. Net $\mathrm{CO}_{2}$ exchange rates of 20-dayold leaves at light saturation were collected with leaves at temperatures $>37 \mathrm{C}$ and $<10 \mathrm{C}$. Growth chambers were used to provide conditions resulting in leaf temperatures up to $37 \mathrm{C}$. Leaf temperatures $>37 \mathrm{C}$ were attained by placing the frame and lamp, covered with black cloth, in direct sunlight outdoors on hot, sunny days during Aug. 1986 in Davis, Calif. While no sunlight penetrated to the leaves, the combination of high air temperature, long-wave radiation absorbed by the black cloth reradiating to the plant, radiation of heat from the lamp, and reduced air circulation resulted in controllable leaf temperatures ranging from 35 to $50 \mathrm{C}$. The interior of the structure was sprayed with deionized water every $5 \mathrm{~min}$ with a spray bottle so that the relative humidity (measured by the LI-COR 6000) was at least $30 \%$ for 